\title{
FOREIGN MARKET SELECTION FACTORS IN THE AUSTRALIAN CONSTRUCTION SERMCES SECTOR
}

\author{
Faiza A. El-Higzi \\ Queensland University of Technology
}

\section{INTRODUCTION}

Recent efforts to improve construction industry performance in Australia have revealed the need for companies to become more competitive internationally (Construction Queensland, 1997). The potential advantages of this for individual companies are manifold: diversification of market portfolios (Strassmann and Wells, 1988), and products and services (Hoopes, 1999; Smyth, 1999; Wolf, 1975; Wolf, 1977); new sources of competitive advantage (Ghoshal, 1987; Porter, 1985); the locational and ownership advantages of overseas markets (Dunning, 1988); increased strategic and operational flexibility to deal with macroeconomic risks (Kogut, 1985); and enhanced global learning (Bartlett and Ghoshal, 1989).

The first step in this is the selection of target foreign markets - an important issue in global expansion and market diversification that has been well researched by international business and marketing scholars (eg. Andersen and Strandskov, 1998; O'Farrell and Wood, 1994; Papadopoulos and Denis, 1988). A related issue is the selection of an appropriate entry mode (Terpstra and Sarathy, 2000). These influence both the amount of staff and capital, i.e. labour, skills, equipment, finance and intangible capital, as well as reputation and risk management capability (Strassmann and Wells, 1988) that firms need to commit to foreign markets, and the performance and longevity of the foreign operations (Anderson and Gatignon, 1986; Hill, Hwang, and Kim, 1990; Li, 1995; Root, 1994).

The construction industry, however, currently lacks an export culture (DISR, 1998; El-Gamal, 1993), with companies being faced with a ".. bewildering array of countries and markets throughout the world..." (Douglas, Craig and Keegan, 1982: 27). Little is known of the factors that influence construction companies' decisions to internationalise operations, how they interplay to influence the choice of a foreign country for entry and the risk factors involved. In seeking to rectify this, this paper considers whether international construction marketing can be approached in the same manner as the marketing of other services. In doing so, this paper aims to contribute to a better understanding of the international marketing of construction services and respond to calls for more research into the foreign entry strategies of various subsectors within the services industry in general (DomkeDamonte, 2000; Ekeledo and Sivakumar, 1998; Erramilli and Rao, 1990).

\section{TARGET COUNTRY SELECTION FACTORS}

\section{Company-specific factors}

Internationalisation of activities and the level of control required to achieve objectives in a foreign market is determined by the corporate objectives and strategic motivations of the firm (Morgan, 1997; Douglas and Craig, 1995; Ekeledo and Sivakumar, 1998). The 'defensive strategy' (Smyth, 1999; White, Griffith and Ryans, 1998) of maintaining client following is one of the first strategies internationalising services companies employ (Erramilli, 1990; Li and Guisinger, 1992; Sapir and Winter, 1994; Terpstra and Yu, 1988). Often, firms expand into international markets at the invitation of existing or potential clients (Phillips, Doole and Lowe, 1994), suppliers and business partners (Erramilli and Rao, 1990), with service firms tending to follow domestic clients overseas (Terpstra and Yu, 1988). This may involve offering new or modified services (Smyth, 1999). Strategic expansion to new clients, through geographic diversification (Cooper and Kleinschmidt, 1985) is often achieved by opening branch offices in one country as a gateway or springboard for neighbouring countries (White et al., 1998) to secure a niche in, or capitalise on, a larger market (Hoopes, 1999; White et al., 1998). The risks are much greater, however, as companies face greater competition for, and uncertainty in the acceptance of, the target customers (Smyth, 1999; Strassmann and Wells, 1988). 
Entry mode decisions are influenced by the degree and type of control desired (Douglas and Craig, 1995). Sole ownership (i.e. FDI, branch/subsidiary) provides the most control but demands substantial financial and human resources to enforce patents and contracts, achieve economies of scale and absorb marketing costs (Stopford and Wells, 1972; Hood and Young, 1979). Firms with limited resources tend to favour licensing or indirect exporting, but with little control over the marketing effort (J ohansson, 2000). A firm's technological expertise and knowledge influences both its choice of target market (El-Gamal, 1993; Porter, 1985; Sugimoto, 1990) and entry mode (Buckley and Casson, 1976; Caves, 1982; Dunning, 1977; Williamson, 1985). Thus, larger firms tend to favour sole ownership or joint venture as there is less chance of exploitation by a local partner (Doz, 1988). A highly committed company, however, is more likely to choose equity entry modes over those offering less control (Root, 1994). Factors such as attitudes of managers, corporate strategy, degree of success in foreign markets and level of international experience are also important (Root, 1994).

Experience in international business, as reflected in the number of foreign markets currently served, ratio of foreign sales to total sales, and knowledge of host country(s) affects entry mode and market selection (Ekeledo and Sivakumar, 1998; Erramilli, 1991; Li and Guisinger, 1992). There is a linear relationship between preference for sole ownership and international experience generally (Gatignon and Anderson, 1988; J ohanson and Vahlne, 1977). In the case of services, however, there is a U-shaped relationship (Erramilli, 1991). As their experience increases, service firms tend to choose markets that are culturally less similar to their home country (Erramilli, 1991; Weinstein, 1977; Ball and Tschoegl, 1982). Also, increased international operations experience is favoured by banks and advertising agencies (Terpstra and Yu, 1988) due to the companies' increased ability to evaluate competition and customer needs, estimate costs and returns and assess the potential of target markets (Cavusgil, 1982; Davidson, 1980a).

\section{Host country factors}

Several economic theories have contributed to understanding trade between nations and foreign entry decisions. The HeckscherOhlin factor proportions theory regards labour and capital as the two factors of production, with technology as the means of combining the two to create a product. Thus, products which are relatively labour intensive tend to be exchanged for capital intensive goods and vice versa (Heckscher, 1949; Ohlin, 1933). Despite its paradoxes (Leontief, 1953) the theory is useful in predicting trade in construction services between developing (labour abundant) and industrialised (capital abundant) nations. Transaction costs theory and eclectic theory, on the other hand, both focus on the trade-off between preferences for control and resource commitment (Hill et al., 1990). The transaction costs perspective implies entry mode is an individual transaction (Gatignon and Anderson, 1988), so that its choice reflects the transaction costs associated with uncertainty, imperfect market knowledge and possible exploitation in contracting agreements. Thus firms begin with direct exporting activities, progressing to more involved entry modes as transaction costs decrease with experience (Meyanathan and Munter, 1994). Transaction costs are also minimised if firms first enter culturally close markets and then move into more distant ones. Eclectic theorysuggests that the choice of entry mode is contingent upon transaction-specific advantages, internalisation-specific advantages and ownership-specific advantages (Dunning, 1988), while stage theory suggests that an export capability is established through a developmental and sequential process (Crick, 1995; J ohanson and Vahlne, 1977). There may be as many as six distinct stages in a firm's progression to entering more risky, less culturally similar markets and making equity investment in offshore sales and manufacturing outlets or FDI (Andersen, 1997; Coviello and Martin, 1999: 226).

The decision to enter a foreign market is made by a firm's managers, and their judgements shape the firm's internationalisation and its consequences (Chetty and Holm, 2000). The normative International Market Selection (IMS) model (Papadopoulos and Denis, 1988) proposes several factors for assessing the potential attractiveness of a target market including user profiles (Root, 1994), market size and growth (Davidson, 1980b; Stobaugh, 1969), competition (Knickerbocker, 1973), servicing costs (Davidson, 1982), and the host country's 
political, economic and social environment (Ostler, 1998; Root, 1987; Toyne and Walters, 1989). By describing the organisation, input-output relationships, size and other features of typical industry and government clients, a profile of actual or potential client organisations can be outlined. This enables the selection of indicators of market size and growth such as industry and company sales potential (Agarwal and Ramaswami, 1992; Terpstra and Yu, 1988), GDP (or GNP) growth and per capita data as well as other relevant socio-economic data (Ostler, 1998; Root, 1994). Firms often establish operations in an unprofitable foreign market simply to monitor competitor activity (Hill et al., 1990; Kim and Hwang, 1992).

There are also inherent political, economic and social risks involved in entering foreign markets (Miller, 1992; Ostler, 1998; Root, 1994). Political risk poses threats to market potential (Miller, 1992) and the safety of personnel (Ostler, 1998), with typical signals being riots, war, revolution or irregular changes in political regimes (coup attempts, coup d'etat) (Shubik, 1983; Ting, 1988) and changes in governments and heads of state (Cosset and Roy, 1991; Cukierman, Edwards and Tabellini, 1992; McKoll-Kennedy and Kiel, 1999). Similarly, fiscal and monetary reforms, threats of expropriation, barriers to earnings repatriation (Strassmann and Wells, 1988), tax discrimination and changes in levels of trade barriers (Barker and Kaynak, 1992), government price controls, attitudes towards foreign investment (Miller, 1992), the adequacy of the legal system and efficiency of public officials (Root, 1994), and inadequate government policy covering the provision of public goods, such as transportation and communications (Miller, 1992), need to be considered.

Linked to political risk are macroeconomic uncertainties (Oxelheim and Wihl borg, 1987; Root, 1994), which include movements in input prices (i.e. raw materials and labour), limited hard currency for international business, and foreign exchange and interest rate fluctuations (Barker and Kaynak, 1992; Yang, Leone and Alden, 1992). Construction also faces special risks in the form of delays in site availability, inclement weather, degree of urbanisation (Akhter, 1995; Cukierman et al., 1992; J iuan, 1993), inappropriate subsoil conditions, labour availability and unrest, raw materials and input shortages (Miller, 1992; Strassmann and Wells, 1988).
Geographic proximity is important as firms may 'creep' into close, new markets where existing plant and equipment are nearby (Davidson and McFetridge, 1985; J iuan, 1993; Ostler, 1998; White et al., 1998).

Cultural differences can make managers feel ignorant and fearful of their capacity to manage, so that their companies stay in "easy" culturally similar markets (Cicic, Patterson and Shoham, 1999; J iuan, 1993; Langhoff, 1996; Petersen and Pedersen, 1996; White et al., 1998) - a tendency known as psychic distance ( ohanson and Vahlne, 1977; J ohanson and WiedershheimPaul, 1975). As a firm's experience in international business grows, the effects of psychic distance decrease (Langhoff, 1996).

Improved market knowledge also encourages companies to invest more resources in the overseas ventures ( ohanson and Vahlne, 1977), as uncertainty and risks are reduced (Cavusgil, 1982). Likewise, familiarity with the indigenous construction environment encourages alliances with indigenous contractors (Ostler, 1998). Unfamiliarity with business protocols and practices (Cheong and Chong, 1988; Morgan, 1997; Yang et al., 1992) can also influence IMS and entry mode decisions.

Also of importance is the attractiveness of the project (Ostler, 1998). The project might be fraught with technical or contractual difficulties. Overall, the potential mismatch between a firm's expertise and local needs needs to be minimised (Craig and Yetton, 1994; Cutler, 1994).

\section{Home country factors}

Porter's (1990) diamond model is appropriate for analysing the international competitiveness of an industry (Öz, 2001). The potential influencing factors are: demand conditions, firm strategy and rivalry, related and supporting industries, and factor endowments, with government and chance influencing their interrelationships (Porter, 1990; Australian Trade Commission, 1994; DISR, 1998). Limited venture capital to fund export involvement and the high cost of finance has an adverse affect on small and medium companies (Australian Trade Commission, 1994; White et al., 1998). Limited market intelligence has also been identified as an organisational export barrier (Barker and Kaynak, 1992; White et al., 1998). 


\section{Global factors}

International finance and aid programs are important (Australian Trade Commission, 1994; Ostler, 1998). International competition is also intense (DISR, 1999; Ostler, 1998; Sugimoto, 1990) and can act as a barrier to trade (Sapir and Winter, 1994). Multinational companies are known to utilise their global strategic motivations (Hill et al., 1990; Morgan, 1997) and economies of scale (Sugimoto, 1990) to remain competitive.

\section{DATA COLLECTION}

A mailed questionnaire obtained details of companies, export profiles and the factors influencing market selection in terms of host country factors, home country factors, company-specific factors and global factors following El-Gamal (1993), Jiuan (1993), Erramilli (1990), Root (1987), Ostler (1998) and the Australian Trade Commission (1994). Answers were solicited using the five point Likert scale with 1 being least important and 5 most important. This was treated as an interval scale as it communicates interval properties to respondents (Schertzer and Kerman, 1985), and is in line with previous studies (J iuan, 1993; El-Gamal, 1993; Sugimoto, 1990).

As Australian construction services companies were the focus of the research is it was essential to access as many companies as was practically possible in these segments. It was also important that the characteristics of the data collected represent the characteristics of the total population (Saunders et al., 1997). To ensure that this process was adhered to the population sample was chosen from Kompass Australia (1999). Kompass Australia is an internationally recognised commercial company directory. The web version of this directory was accessed for the provision of preliminary information about the research sample. The Kompass Australia directory divides the building and construction industry companies into groups and sub-groups according to their technical representation. All these groups were considered and only companies registered as exporters of construction services were used in the survey sample. Building materials contractors and suppliers were excluded.

The sub-groups chosen for the survey sample are referred to as cluster samples (Emroy and Cooper, 1991). It was also decided, for the objectives of the research to include only those companies involved in the provision of international construction services. As participants in the final selected subgroups were chosen by the researcher, the survey sample is classified as a judgmental cluster sample ( Hussey and Hussey, 1997). It is important to note that cluster sampling is known to provide unbiased estimates of the population parameters (Emroy and Cooper, 1991).

The total response rate was $34.3 \%$, comprising 105 companies representing design, engineering, construction and contracting services. The number of employees in these companies ranges from 3 to 3000 worldwide. For reasons of convenience four of the south east Queensland respondents were approached ÁNAinterieiews.

\section{Company profile}

More than three quarters of the respondents' companies are 100\% Australian owned, with $8.7 \%$ being "international" companies with no Australian ownership and the remaining $13 \%$ being companies with combined ownership. Of the companies, $60.9 \%$ are small and medium enterprises (SME). The largest percentage of entry mode is export (46.4\%), with joint ventures next (21.7 \%). The respondents' companies offer a range of international services, with $30.4 \%$ offering all services and $26.1 \%$ offering preconstruction services including engineering and architectural design. Developing and newly industrialised economies are the largest target market groups at $34.8 \%$.

\section{Company-specific factors influencing market selection}

Table 1 summarises the results for the company-specific factors influencing market selection. Variables were ranked according to their mean scores and grouped by the method of least significant difference (LSD). This produced three sub-groups each for SMEs and multinational enterprises (MNEs). For example, the Small and Medium Enterprise group comprised subgroup A, consisting of desire to expand strategically, project nature and future potential, company strength in know-how and project funding. These variables are primarily project related variables and company strategic motivation factors. Subgroup B, on the other hand, contained strategic motivation and 
market variables and subgroup $C$ contains project, market and strategic motivation variables. For the MNE group, subgroup A contained strategic motivation, market and project variables, with subgroup B containing project, market and strategic motivation variables and subgroup $C$ containing export credit insurance.

For the MNEs and SMEs, the three most important variables explaining their reasons for entering foreign markets were desire to expand geographically, project nature and future potential, and company strength in know-how. These are company motivation and project related factors. However, the mean score for MNEs is much higher for these variables than for the SMEs. In addition, the mean scores for all factor groups in both samples indicate company motivation and project nature plus company strength to be the most important variables for choosing country of entry.
The interviews revealed that nominal presence to MNEs is important when the market potential is great, but branch offices had to be "financially viable". Market similarity was "not a primary consideration" because major international projects are infrastructure projects that are part of international consortia. The only consideration then is "if there is some local expertise that you can use". Technology transfer had two aspects for consideration: the host government point of view on "the way they want to build their facility" and "duration of the project, and what you see your role in the country". A suitable joint venture partner was seen as "... someone who knows their way around the city, who have the right contacts in the government and the industry. Someone with competency skills."

Table 1: Company-specific factors, descending means and sub-groups

\begin{tabular}{|l|c|c|c|c|}
\hline \multirow{2}{*}{ Variable } & \multicolumn{2}{|c|}{ SME } & \multicolumn{2}{c|}{ MNE } \\
\cline { 2 - 5 } & Mean & Group & Mean & Group \\
\hline Desire to expand strategically & 4.29 & A & 4.56 & A \\
\hline Project nature and future potential & 4.21 & A & 4.33 & A \\
\hline Company strength in know-how & 4.21 & A & 4.33 & A \\
\hline Project funding & 3.86 & A & 3.56 & B \\
\hline Desire to expand geographically & 3.79 & B & 4.33 & A \\
\hline Profitability & 3.64 & B & 4.33 & A \\
\hline Cost of market entry & 3.43 & B & 4 & A \\
\hline Quick entry into market & 3.21 & B & 3.33 & B \\
\hline Suitable host country partner & 3.14 & B & 3.11 & B \\
\hline Technology transfer & 2.86 & C & 2.89 & B \\
\hline Market similarity & 2.79 & C & 3.33 & B \\
\hline Nominal presence & 2.71 & C & 3.33 & B \\
\hline Follow a domestic client overseas & 2.63 & C & 3 & B \\
\hline Export credit insurance & 2.57 & C & 2.33 & C \\
\hline Intensity of global competition in & 2.50 & C & 2.89 & B \\
host country & & & & \\
\hline Suitable home country partner & 2.29 & C & 3.11 & B \\
\hline
\end{tabular}


MNEs had six variables in the first subgroup and four in the last subgroup while SMEs had four in the first subgroup and eight in the last subgroup. This suggests that there is a greater interplay of issues for MNEs than SMEs. It was also noted that the variables in each sub-group are project related, market related and company motivation related issues, suggesting the interplay of many variables. It is also clear that project related factors and company motivations were significantly more important than variables in the host country and home country factor groups.

\section{Host country factors influencing market selection}

Variables with high mean values in the host country factors for SMEs were mostly policy (profit repatriation, trade barriers) and structural variables (foreign exchange control, tax discrimination and ease of foreign investment procedures) (Table 2). Political stability of the host country also scored a high mean value (3.79) as did market size and problems with collectibles. The table shows that MNEs share the first three variables with SMEs. They also rank problems with collectibles, ease of foreign investment procedures and degree of urbanisation as more important than do SMEs.

Problems with collectibles had an A ranking for MNEs, attracting the comment from an export manager interviewed "... you have to look at the cost of opportunity, if you don't get paid or are unable to repatriate your profits, or you are double taxed, then the pot of gold you have made is not worth the struggle".

Table 2: Host country factors analysis by descending means and sub-groups

\begin{tabular}{|l|c|c|c|c|}
\hline \multirow{2}{*}{ Variable } & \multicolumn{2}{|c|}{ SME } & \multicolumn{2}{c|}{ MNE } \\
\cline { 2 - 5 } & Mean & Group & Mean & Group \\
\hline Profit repatriation & 3.86 & A & 4.22 & A \\
\hline Political stability & 3.79 & A & 4.22 & A \\
\hline Foreign exchange control & 3.50 & A & 3.89 & A \\
\hline Trade barriers & 3.50 & A & 3.22 & D \\
\hline Tax discrimination & 3.43 & A & 3.67 & B \\
\hline Host country market size & 3.43 & A & 3.44 & D \\
\hline High economic performance & 3.29 & A & 3.56 & D \\
\hline Competition intensity in host country & 3.29 & A & 3.22 & D \\
\hline Ease of foreign investment procedures & 3.21 & B & 3.67 & B \\
\hline External debt servicing ability & 3.21 & B & 3.00 & D \\
\hline Problems with collectibles & 3.07 & B & 3.89 & A \\
\hline Degree of urbanisation & 3.07 & B & 3.67 & C \\
\hline Skill of workforce and quality of output & 3.00 & B & 3.22 & D \\
\hline GDP per capita & 3.00 & B & 2.67 & F \\
\hline Geographical proximity & 2.93 & B & 3.56 & E \\
\hline Less-developed infra-structural system & 2.93 & B & 3.00 & E \\
\hline Services liability & 2.86 & B & 3.22 & D \\
\hline Less- developed legal system & 2.86 & B & 2.67 & F \\
\hline Cultural similarity & 2.79 & B & 2.89 & E \\
\hline Restriction on foreign ownership & 2.71 & B & 3.33 & D \\
\hline Employee self-interested behaviour & 2.71 & B & 3.00 & E \\
\hline Natural disasters & 2.29 & C & 2.22 & F \\
\hline
\end{tabular}


Some of the variables that were expected to be of significant importance to the construction industry in Australia were cultural similarity, geographical proximity, skill of the workforce and quality of the output, and the legal system of the host country. However, none of these were in the A, B or even C groups. One possible explanation is that most of the respondents were SMEs, with export as their dominant entry mode. This reinforces the view that respondents see overseas operations as secondary to their domestic operations. This suggests that these companies are still in the first stages of their internationalisation process and lack market knowledge and experience.

While SMEs had only two dominant subgroups and a third that consisted of only one variable, MNEs had six equal mean subgroups, indicating that the MNE respondents are more sensitive to the degree of importance and significance of variables than SME respondents. It was noted that none of the sub-groups comprised a single factor group (structural, economic or policy) but were of different themes, highlighting the inter-play among the different variables.

\section{Home country factors influencing} market selection

Variables in home country factors were structural factors, market factors and production factors. Table 3 summarises the results for the SMEs and MNEs. This shows the first two variables - home country demand fluctuation and intensity of competition at home - are the same for the two company size groups. It was also noted that for the SMEs, reliable and timely information, and availability of finance are more important than for MNEs, which agrees with the view of the Australian Trade Commission (1994), that SMEs rely on home government market intelligence and funding support. "We haven't been picking and choosing, we deal with Austrade and other government agencies, and for our last job Austrade contacted us," said the manager of one SME. On finance, another manager of another SME said, "We are now applying for the EMDG program and are on Austrade's list. They sure help."

Table 3: SME home country factors descending means and equal mean sub-groups

\begin{tabular}{|l|c|c|c|c|}
\hline \multirow{2}{*}{ Variable } & \multicolumn{2}{|c|}{ SME } & \multicolumn{2}{c|}{ MNE } \\
\cline { 2 - 5 } & Mean & Group & Mean & Group \\
\hline Home country market demand fluctuation & 3.36 & A & 3.89 & A \\
\hline Intensity of competition in home country & 3.36 & B & 3.89 & A \\
\hline Reliable and timely information & 3.36 & B & 2.86 & B \\
\hline Availability of finance & 3.36 & B & 2.44 & B \\
\hline Tax incentives with host country & 3.21 & B & 2.33 & B \\
\hline $\begin{array}{l}\text { Home government policy towards foreign } \\
\text { investment }\end{array}$ & 3.00 & B & 3.11 & A \\
\hline Home country economic treaty with host & 2.93 & B & 2.67 & B \\
\hline Part of an aid program & 2.86 & B & 2.78 & B \\
\hline High costs of operation in home country & 2.77 & B & 2.56 & B \\
\hline
\end{tabular}


It was also noted that home government policy issues were less significant than host government policies. For SME respondents, tax incentives, home government policy towards foreign investment, economic treaties and aid programs were rated $5^{\text {th }}, 6^{\text {th }}$, and $7^{\text {th }}$ and $8^{\text {th }}$. Apart from tax incentives (3.21 for SMEs and 2.33 for MNEs), other variables scored relatively close mean scores. Tax incentives with host countries include double taxation treaties, and profit repatriation schemes as well as basic tax rates. Apart from the view reported above regarding difficulties with taxation and repatriation of profits perhaps resulting in the struggle "not being worth it", others managed to write the risks associated off: "... if we pay the tax, we build it in our contract." Taxation is therefore treated as a business risk that is evaluated and compensated for before commencing construction works.

Again, the differences in orientation of SMEs and MNEs towards overseas involvement explain the complexity and degree of importance of the issues that interplay. As MNEs are oriented towards long-term involvement in overseas operations, they consider home government policy towards foreign investment a more important variable than do SMEs

\section{Global factors influencing market selection}

Global factors for consideration were global competition, following competitors overseas, and international finance. Table 4 summarises the results. It is interesting to note that the international finance mean value was the least for the MNE respondents and most of for the SME respondents.

\section{COMMON VARIABLES}

Common variables for the MNE and SME respondents are shown in Table 5 . The company motivation factors of desire to expand strategically and profit repatriation were in the A group, together with projectspecific variables of project nature and future potential, and company strength of expertise. Table 5 shows that group B has 10 variables. These include the company motivations of desire to expand strategically and profitability, as well as project factors, home market factors and structural factors of the host country. It is interesting to note that market factors scored higher means than some foreign investment policy issues at the host country level.

Group C primarily comprises host country structural and policy issues, but it also includes variables at the home country policy level. The availability of a suitable host country partner did not seem to have a significant effect contrary to what Erramilli (1990) found at the services sector level. This may be due to the profile of the respondents and their predominant entry mode. Of the three remaining groups, $\mathrm{D}$ included all remaining variables but two, which belonged to $\mathrm{E}$ and $\mathrm{F}$ groups. All global variables were part of the $D$ sub-group, indicating their relative lack of importance.

Table 4: Gl obal factors descending means and sub-groups for SMEs and MNEs

\begin{tabular}{|l|c|c|c|c|}
\hline \multirow{2}{*}{ Variable } & \multicolumn{2}{|c|}{ SME } & \multicolumn{2}{c|}{ MNE } \\
\cline { 2 - 5 } & Mean & Group & Mean & Group \\
\hline Global competition & 2.71 & $\mathrm{~A}$ & 3.11 & $\mathrm{~A}$ \\
\hline Follow competitors overseas & 2.50 & $\mathrm{~A}$ & 2.67 & $\mathrm{~A}$ \\
\hline Availability of international finance & 3.07 & $\mathrm{~A}$ & 2.63 & $\mathrm{~A}$ \\
\hline
\end{tabular}


Table 5: Common variables by sub-groups

\begin{tabular}{|c|c|c|}
\hline Variable & $\begin{array}{l}\text { Descending } \\
\text { mean }\end{array}$ & Group \\
\hline Desire to expand strategically & 4.39 & A \\
\hline Project nature and future potential & 4.26 & A \\
\hline Company strength in know-how & 4.26 & A \\
\hline Profit repatriation & 4.00 & A \\
\hline Desire to expand geographically & 4.00 & $\mathrm{~B}$ \\
\hline Political stability & 3.96 & $\mathrm{~B}$ \\
\hline Profitability & 3.91 & $\mathrm{~B}$ \\
\hline Home country demand fluctuation & 3.74 & $\mathrm{~B}$ \\
\hline Project funding & 3.74 & $\mathrm{~B}$ \\
\hline Foreign exchange control & 3.65 & B \\
\hline Cost of market entry & 3.65 & $\mathrm{~B}$ \\
\hline Intensity of competition in home country & 3.57 & $\mathrm{~B}$ \\
\hline Tax discrimination & 3.52 & $\mathrm{~B}$ \\
\hline High economic performance & 3.39 & $\mathrm{C}$ \\
\hline Ease of foreign investment procedures & 3.39 & $\mathrm{C}$ \\
\hline Host country market size & 3.39 & $\mathrm{C}$ \\
\hline Trade barriers & 3.39 & $\mathrm{C}$ \\
\hline Problems with collectibles & 3.39 & $\mathrm{C}$ \\
\hline Competition intensity in host country & 3.26 & $\mathrm{C}$ \\
\hline Quick entry into market & 3.26 & $\mathrm{C}$ \\
\hline Geographical proximity & 3.17 & $\mathrm{C}$ \\
\hline External debt servicing ability & 3.13 & $\mathrm{C}$ \\
\hline Skill of workforce and quality of output & 3.09 & $\mathrm{C}$ \\
\hline Home government policy towards foreign investment & 3.04 & $\mathrm{C}$ \\
\hline Reliable and timely information & 3.04 & $\mathrm{C}$ \\
\hline Suitable host country partner & 3.04 & $\mathrm{C}$ \\
\hline Services liability & 3.00 & $\mathrm{C}$ \\
\hline Availability of finance & 3.00 & $\mathrm{C}$ \\
\hline Market similarity & 3.00 & $\mathrm{C}$ \\
\hline Less-developed infra-structural system & 2.96 & $\mathrm{D}$ \\
\hline Restriction on foreign ownership & 2.96 & $\mathrm{D}$ \\
\hline Nominal presence & 2.96 & $\mathrm{D}$ \\
\hline Less-developed legal system & 3.17 & $\mathrm{C}$ \\
\hline Restriction on foreign ownership & 2.96 & $\mathrm{D}$ \\
\hline Nominal presence & 2.96 & $\mathrm{D}$ \\
\hline Degree of urbanisation & 2.91 & $\mathrm{D}$ \\
\hline Global competition & 2.91 & $\mathrm{D}$ \\
\hline Tax incentives with host country & 2.87 & $\mathrm{D}$ \\
\hline
\end{tabular}




\begin{tabular}{|l|c|c|}
\hline Table 5 (continued) & $\begin{array}{c}\text { Descending } \\
\text { mean }\end{array}$ & Group \\
\hline Variable & 2.87 & D \\
\hline Technology transfer & 2.86 & D \\
\hline GDP per capita & 2.83 & D \\
\hline Cultural similarity & 2.83 & D \\
\hline Employee self-interested behaviour & 2.83 & D \\
\hline Home country economic treaty with host nation & 2.83 & D \\
\hline Part of an aid program & 2.78 & D \\
\hline Less- developed legal system & 2.77 & D \\
\hline Follow a domestic client overseas & 2.68 & D \\
\hline High costs of operation in home country & 2.65 & \\
\hline Intensity of global competition in host country & 2.58 & D \\
\hline Follow competitors overseas & 2.48 & D \\
\hline Export credit insurance & 2.35 & E \\
\hline Availability of international finance & 2.30 & E \\
\hline Suitable home country partner & 2.26 & F \\
\hline Natural disasters & & \\
\hline
\end{tabular}

\section{CONCLUSION}

The survey of Australian construction companies found the choice of overseas country of entry is not only the outcome of the host country's economic, political and structural factors, but also a result of the interplay of the company's motivations for expansion, and the availability of a relevant construction project. Other factors at the host country level and home country level, and the global and company level influence the company's approach to the overseas operation but do not significantly influence the decision of choice of country of entry.

Of major significance is the finding that trade in construction services is primarily with developing and newly industrialised economies. According to the factor proportions theory, this suggests that trade is a result of the technological superiority of the Australian companies involved, a conclusion reinforced by the generally high scores for company strength in expertise, and project nature and future potential. From a stage models perspective, the use of low-resource commitment methods of market entry suggests that the Australian companies' level of market knowledge and experience is insufficient to inspire confidence in investment in overseas operations. It also implies that Australian companies are just beginning to develop an export culture and therefore consider international operations to be secondary to their domestic activities. The transaction cost model, on the other hand, suggests that the companies involved are opting for the low-risk/low return modes of entry and consequently short-term involvement in overseas ventures. Competitive intensity and organisational goals were also significant factors, as predicted by the conceptual model of contingencies. Also, as the study used entry mode variables and tested them at the country of entry choice level, it can be concluded that international entry mode models and frameworks can be used to determine foreign market selection variables.

Equally important is the finding that export is the dominant entry mode of the respondents, suggesting that companies are driven by the intensity of domestic competition and fluctuating domestic demand to seek overseas ventures and so increase their profit margins. The company's expertise is another significant factor; other factors are investment policy variables that influence the flow of trade and investment between countries such as profit repatriation, trade 
barriers and tax discrimination. The major international business risks are political instability and problems with collectibles.

\section{Acknowledgements}

Thanks to Keith Hampson, Sherif Mohamed, Stephen Kajewski, Martin Skitmore and those organisations and individuals who took the time to participate in the questionnaire and interviews. Special thanks to Andrea Insch for help with rewrites.

\section{REFERENCES}

Agarwal, S. and Ramaswami, S. (1992) Choice of foreign market entry mode: impact of ownership, location and internalization factors. Journal of International Business Studies, 23 (1), 1-27.

Akhter, S. H. (1995). Global marketing: concepts, strategies, practice, text and readings (2nd ed.). South-Western College Publishing, Cincinnati.

Andersen, O. (1997) Internationalization and market entry mode: a review of theories and conceptual frameworks. Management International Review, 37 (2), 27-42.

Andersen, P. and Strandskov, J . (1998) International market selection: a cognitive mapping perspective. Journal of Global Marketing, 11 (3), 65-84.

Anderson, E., and Gatignon, H. (1986) Modes of Foreign Entry: A Transaction Cost Analysis and Propositions. Journal of International Business Studies, 17 (3), 1-26.

Anderson, O. (1993) On internationalisation process of firms: a critical analysis. Journal of International Business Studies, 24 (2), 209-231.

Australian Trade Commission (1994) Intelligent Exports: and "The Silent Revolution in Services". Commonwealth of Australia, Sydney.

Ball, C. A. and Tschoegl, A. E. (1982) The Decision to Establish a Foreign Bank Branch of Subsidiary. Journal of Financial and Quantitative Analysis, 17 (3), 411-424.

Barkema, H., Bell, J . and Pennings, J . (1996) Foreign Entry, Cultural Barriers, and Learning. Strategic Management Journal, 17 (February), 151-166.

Barker, A. T. and Kaynak, E. (1992) An Empirical Investigation of the Differences Between Initiating and Continuing Exporters. European Journal of Marketing, 26 (3), 27-36.
Bartlett, C. A. and Ghoshal, S. (1989) Managing across borders: the transnational solution. Harvard Business School Press, Boston.

Bilkey, W. J . and Tesar, G. (1977) The Export Behavior of Smaller Sized Wisconsin Manufacturing Firms. Journal of International Business Studies, 8 (1), 93-98.

Buckley, P. J. and Casson, M. (1976). The future of the multinational enterprise. Macmillan, London.

Caves, R. E. (1982) Multinational Enterprise and Economic Analysis. Cambridge University Press, New York.

Canusgil, S. T. (1982) Some Observations on the Relevance of the Critical Variables for Internationalization Stages. In: Czinkota, M. R. (ed.), Export Management Praeger, New York.

Cheong, W. K. and Chong, K. W. (1988) Export Behavior of Small Firms in Singapore. International Small Business J ournal, 6 (2), 34-41.

Chetty, S. and Holm, D. (2000) Internationalisation of small to medium-sized manufacturing firms: a network approach. International Business Review, 9, 77-93.

Cicic, M., Patterson, P. and Shoham, A. (1999) A conceptual model of the internationalization of services firms. Journal of Global Marketing, 12 (1), 81-106.

Construction Queensland (1997) Construction Queensland: the Direction. Construction Queensland, Brisbane

Cooper, D. and Emroy, W. (1995) Business Research Methods. Irwin, USA.

Cooper, R. and Kleinschmidt, E. (1985) The Impact of Export Strategy on Export Sales Performance. J ournal of International Business Studies, 16 (1), 37-55.

Cosset, J .-C. and Roy, J . (1991) The Determinants of Country Risk Ratings. J ournal of International Business Studies, 22 (1), 135-142.

Coviello, N. E. and Martin, K. A.-M. (1999) Internationalization of service SMEs: An integrated perspective from the engineering consulting sector. Journal of International Marketing, 7 (4), 42-66.

Craig, J. and Yetton, P. (1994) Australia's international firms: Contributions and prospects. In: Marsh, I. (ed.), Australian Business in the Asia Pacific Region: The Case for 
Strategic Industry Policy. Longman Professional, Melbourne.

Crick, D. (1995) An Investigation into the Targeting of UK Export Assistance. European J ournal of Marketing, 29 (8), 76-94.

Cukierman, A., Edwards, S. and Tabellini, G. (1992) Seigniorage and Political Instability. The American Economics Review, 82 (3), 537-555.

Cutler, T. (1994) Telecommunications in the future Australian economy: An electronic Switzerland or an electronic backwater. In: Marsh I. (ed.) Australian Business in the Asia Pacific Region: The Case for Strategic Industry Policy. Longman Professional, Melbourne.

Davidson, W. H. (1980a) Experience Effects in International Investment and Technology Transfer. UMI, Ann Arbor.

Davidson, W. H. (1980b) The Location of Foreign Investment Activity: Country Characteristics and Experience Effects. Journal of International Business Studies, 11 (2), 9-23.

Davidson, W. H. (1982) Global strategic management. J ohn Wiley and Sons, New York.

Davidson, W. H. and McFetridge, D. G. (1985) Key Characteristics in the Choice of International Technology Transfer Mode. J ournal of International Business Studies, Summer, 5-21.

DISR (1998) Australia's Building and Construction Exports, Current Performance And Future Opportunities. Department of Industry Science and Resources, Commonwealth of Australia, Canberra.

DISR (1999). Building for Growth, an Analysis of the Australian Building and Construction Industries. Department of Industry Science and Resources, Commonwealth of Australia, Canberra.

Domke-Damonte, D. (2000) Interactive effects of international strategy and throughput technology on entry mode for services firms. Management International Review, 40 (1), 41-59.

Douglas, S., Craig, C. and Keegan, W. (1982) Approaches to assessing international marketing opportunities for small and medium sized enterprises. Columbia Journal of World Business, Fall, 26-32.
Douglas, S. P., and Craig, C. S. (1995). Global Marketing Strategy (International Edition). McGraw Hill, New York.

Dow, D. (2000) A note on psychological distance and export market selection. J ournal of International Marketing, 8 (1), 51-64.

Doz, Y. L. (1988) Technology Partnerships Between Larger and Smaller Firms: Some Critical Issues. International Journal of Management and Organization, 17 (4), 31-57.

Dunn, J . (1983) Country risk: Social and cultural aspects. In: Herring, R. J . (ed.), Managing international risk: Cambridge University Press, New York.

Dunning, J . (1988) The eclectic paradigm of international production: a restatement and some possible extensions. J ournal of International Business Studies, 19, 1-31.

Dunning, J. H. (1977) Trade Location of Economic Activity and the MNE: A Search for an Eclectic Approach. In: Ohlin, B., Hesselborn, P.-O. and Wijkman, P. M. (eds.), The International Allocation of Economic Activity. Homes and Meier, New York.

Ekeledo, I., and Sivakumar, K. (1998) Foreign market entry mode choice of service firms: A contingency perspective. Academy of Marketing Science. J ournal, 26(4), 274-292.

El-Gamal, A. (1993) Towards an Australian Strategic Approach to the International Construction Market. Queensland University Of Technology, Brisbane.

Erramilli, M. K. (1990) Entry Mode Choice in Services Industries. International Marketing Review, 7 (5), 50-62.

Erramilli, M. K. (1991) The Experience Factor in Foreign Market Entry Behavior of Service Firms. Journal of International Business Studies, 22 (3), 479-501.

Erramilli, M. K. and Rao, C. (1990) Choice of foreign market entry mode by service firms: role of market knowledge. Management International Review, 30 (2), 135-150.

Gatignon, H. and Anderson, E. (1988) The Multinational Corporation's Degree of Control over Foreign Subsidiaries: An Empirical Test of a Transaction Cost Explanation. Journal of Law, Economics and Organization, 4, Fall, 305-336.

Ghoshal, S. (1987) Global Strategy: An Organizing Framework. Strategic Management J ournal, 8 (5), 425-450. 
Heckscher, E. (1949) The Effect of Foreign Trade on the Distribution of Income. In: Ellis, H. S. and Metzler, L. A. (eds.), Readings in International Trade. The Blakiston Company, Philadel phia.

Hill, C. W., Hwang, P. and Kim, W. C. (1990) An Eclectic Theory of the Choice of the International Entry Mode. Strategic Management J ournal, 11 (2), 117-128.

Hood, N. and Young, S. (1979) The Economics of Multinational Enterprise. Longman Group, London.

Hoopes, D. G. (1999) Measuring geographic diversification and product diversification. Management International Review; Wiesbaden, 3, 277-292.

J iuan, T. S. (1993) Determining Entry Mode Strategies for International Markets: $A$ Managerial Choice Approach. Unpublished PhD Thesis, Washington University.

J ohanson, J. and Vahlne, J.-E. (1977) The Internationalisation Process of the Firm: A Model of Knowledge Development and Increasing Foreign Commitments. Journal of International Business Studies, 8 (1), 23-32.

J ohanson, J. and Wiedershheim-Paul, F. (1975) The Internationalisation of the Firm: Four Swedish Cases. Journal of Management Studies, 12, October, 305-322.

J ohansson, J. K. (2000) Global Marketing: Foreign Entry, Local Marketing and Global Management (2nd Edition). Irwin, Chicago.

Kim, W. and Hwang, P. (1992) Global strategy and multinational's entry mode choice. Journal of International Business Studies, 31 (2), 29-53.

Knickerbocker, F. T. (1973) Oligopolistic reaction and multinational enterprise. Division of Research, Harvard Business School, Boston.

Kogut, B. (1985) Designing Global Strategies: Profiting from Operational Flexibility (Part 1). Sloan Management Review, 27 (1), 27-38.

Kompass Australia (1999) Kompass: The Business to Business Search Engine. APN Publishing Business. www.kompass.com/kintl.

Langhoff, T. (1996) The influence of cultural differences on internationalisation processes of the firm. In: Bjorkman, I. and Forsgren, M. (eds.) The nature of the international firm. Handelshojskolens Forlag, Copenhagen.
Leontief, W. (1953) Domestic production and foreign trade: the American capital position re-examined. Proceedings of the American Philosophical Society, 97.

Li, J . (1995) Foreign Entry and Survival: Effects of Strategic Choices on Performance in International Markets. Strategic Management J ournal, 16, J une, 333-351.

Li, J. T. and Guisinger, S. (1992) The Globalization of Service Multinationals in the 'Triad' Regions: J apan, Western Europe and North America. Journal of International Business Studies, 23 (4), 675-696.

McKoll-Kennedy, J . R. and Kiel, G. C. (1999) Marketing a Strategic Approach (Beta Edition ) Nelson ITP, Melbourne.

Meyanathan, S. D. and Munter, R. (1994) Industrial Structures and the Development of Small and Medium Enterprise Linkages: An Overview. In: Meyanathan, S. D. (ed.), Industrial Structures and the Development of Small and Medium Enterprise Linkages: The World Bank, Washington, D.C.

Miller, K. D. (1992) A Framework for Integrated Risk Management in International Business. J ournal of International Business Studies, 23 (2), 311-331.

Morgan, R. E. (1997) Export Stimuli and Export Barriers, Evidence from Empirical Research Studies. European Business Review, 97 (2), 68-79.

O'Farrell, P. and Wood, P. (1994) International market selection by business service firms: key conceptual methodological issues. International Business Review, 3 (3), 243-261.

Ohlin, B. (1933) Interregional and International Trade. Harvard University Press, Boston.

Ostler, C. H. (1998) Country Analysis, Its Role in the International Construction Industry's Strategic Planning Procedure. Paper presented at the Opportunities And Strategies in a Global Market Place, First International Construction Marketing Conference, Construction Management Group, School of Civil Engineering, University of Leeds.

Oxelheim, L. and Wihlborg, C. G. (1987) Macroeconomic uncertainty: International risk and opportunities for the corporation. J ohn Wiley and Sons, New York. 
Öz, Ö. (2001) Sources of competitive advantage of Turkish construction companies in international markets. Construction Management and Economics, 19, 135-144.

Papadopoulos, N. and Denis, J . (1988) Inventory, taxonomy and assessment of methods for international marketing selection. International Marketing Review, 5 (3), 38-51.

Petersen, B. and Pedersen, T. (1996) Twenty years after - support and critique of the Uppsala internationalisation model. In: Bjorkman, I. and Forsgren, M. (eds.) The nature of the international firm. Handelshojskolens Forlag, Copenhagen.

Phillips, C., Doole, I. and Lowe, R. (1994) International marketing strategy : analysis, development and implementation. Routledge, London.

Porter, M. E. (1985) Competitive advantage: creating and sustaining superior performance. Free Press, New York.

Porter, M. E. (1990) The Competitive Advantage of Nations. Free Press, New York.

Root, F. (1987). Foreign Market Entry Strategies. AMACOM, New York.

Root, F. (1994) Entry Strategies for International Markets. D.C. Heath, Lexington, MA.

Sapir, A. and Winter, C. (1994) Services Trade. In: Greenway, P. and Winters, L. A. (eds.) Surveys In International Trade. Blackwell, Oxford, UK.

Shubik, M. (1983) Political risk: analysis, process and purpose. In: Herring. R. (ed.) Managing International Risk. Cambridge University Press, New York.

Smyth, H. (1999) Marketing and Selling Construction Services. Blackwell Science, Oxford.

Stobaugh, R. (1969) How to analyze foreign investment climates. Harvard Business Review, September-October, 100-108.

Stopford, J . M. and Wells, L. (1972. Managing the Multinational Enterprise. Basic Books. New York.

Strassmann, W. P. and Wells, J . (1988) The Global Construction Industry: Strategic for
Entry, Growth and Survival. Unwin Hyman, London.

Sugimoto, F. (1990) Globalisation of International Engineering and Construction Firms for Building their Competitivenes. Unpublished $\mathrm{PhD}$ Thesis, Massachusetts Institute Of Technology.

Terpstra, V. and Sarathy, R. (2000) International Marketing (8th ed.). The Dryden Press, Fort Worth, TX

Terpstra, V. and Yu, C.-M. (1988) Determinants of Foreign Direct Investment in US Advertising Agencies. Journal Of International Business Studies, 19 (1), 33-47.

Ting, W. (1988) Multinational Risk Assessment and Management. Greenwood Press, Westport, Conn.

Toyne, B. and Walters, P. G. P. (1989) Global marketing management: $A$ strategic perspective. Allyn and Bacon, Boston.

Weinstein, A. K. (1977) Foreign Investments by Service Firms: The Case of the Multinational Advertising Agencies. Journal of International Business Studies, 8 (1), 83-92.

White, D. S., Griffith, D. A., and Ryans, J. (1998) Measuring Export Performance in Services Industries. International Marketing Review, 15( 3), 68-79.

Williamson, O. E. (1985) The Economics Institutions of Capitalism. The Free Press, New York.

Wolf, B. M. (1975) Size and Profitability Among US Manufacturing Firms: Multinational Versus Primarily Domestic Firms. Journal of Economics and Business, 28, 15-22.

Wolf, B. M. (1977) Industrial diversification and internationalization: some empirical evidence. The J ournal of Industrial EconomiCS, 26 (2), 177-191.

Yang, Y. S., Leone, R. P. and Alden, D. L. (1992) A Market Expansion Ability Approach to Identifying Potential Exporters. J ournal of Marketing, 56 (1), 84-96. 